\title{
EULER HARMONIC IDENTITIES AND MOMENTS OF REAL BOREL MEASURES
}

\author{
A. Čivluak, Lu. Dedić And M. Matić
}

Abstract. Generalizations of Euler identities involving $\mu$-harmonic sequences of functions and moments of real Borel measure $\mu$ are established. Some Ostrowski and Euler-Grüss type inequalities for functions of various classes are proved.

Mathematics subject classification (2000): 28A25, 26D15, 26D20, $26 \mathrm{D} 99$.

Keywords and phrases: Ostrowski inequality, Grüss-type inequalities, real Borel measures.

\section{REFERENCES}

[1] A. ČIVlJaK, LJ. Dedić AND M. Matić, On Ostrowski and Euler-Grüss type inequalities involving measures, Journal of Mathematical Inequalities, 1, 1 (2007), 65-81.

[2] A. ČIVLJAK, LJ. DEDIĆ AND M. MaTiĆ, On an integration-by-parts formula for measures, Journal of Inequalities in Pure and Applied Mathematics, 8, 4 (2007), Article 93, 13 pp.

[3] A. Ċivljak, Lu. Dedić And M. Matić, Euler-Grüss type inequalities involving measures, International Series of Numerical Mathematics, Birkhäuser Verlag Basel/Switzerland, Vol. 157 (2008), 109_ 120, 2008.

[4] A. ČIVLJAK, Lu. Dedić And M. Matić, Euler harmonic identities for measures, Nonlinear Functional Analysis and Applications, 12, 3 (2007), 343-361.

[5] M. MAtić, J. PEČARIĆ And N. Ujević, Generalizations of weighted version of Ostrowski's inequality and some related results, Journal of Inequalities and Applications, 5 (2000), 639-666. 